Original article

\title{
Geological risk assessment for rock art protection in karstic caves (Alkerdi Caves, Navarre, Spain)
}

\author{
Irantzu Álvarez ${ }^{\mathrm{a}, *}$, Arantxa Bodego ${ }^{\mathrm{b}, \mathrm{d}}$, Arantza Aranburuc, ${ }^{\mathrm{c},}$, Martin Arriolabengoa ${ }^{\mathrm{c}, \mathrm{d}}$, \\ Miren del Val ${ }^{\mathrm{c}, \mathrm{d}}$, Eneko Iriarte ${ }^{\mathrm{d}, \mathrm{e}}$, Víctor Abendaño ${ }^{\mathrm{f}}$, José Ignacio Calvo ${ }^{\mathrm{f}}$, \\ Diego Garate Maidagan ${ }^{\mathrm{g}}$, Arturo Hermoso de Mendoza ${ }^{\mathrm{f}}$, Fernando Ibarra ${ }^{\mathrm{f}}$, \\ Jaime Legarrea $^{f}$, Jesus Tapia Sagarna ${ }^{\mathrm{d}}$, Juantxo Agirre Mauleon ${ }^{\mathrm{d}}$ \\ a Department of Graphic Expression and Engineering Projects, UPV/EHU, Rafael Moreno "Pitxitxi" n' 2, 48013 Bilbao, Spain \\ ${ }^{\mathrm{b}}$ Department of Stratigraphy and Palaeontology, Faculty of Science and Technology, UPV/EHU, Sarriena s/n 48940, Leioa, Spain \\ ${ }^{c}$ Department of Mineralogy and Petrology, Faculty of Science and Technology, UPV/EHU, Sarriena s/n 48940, Leioa, Spain \\ d Aranzadi Zientzia Elkartea, Zorroagagaina, 11, 20014 Donostia-San Sebastián, Spain \\ e Laboratorio de Evolución Humana, Universidad de Burgos, Pl. Misael Bañuelos s/n, 09001 Burgos, Spain \\ ${ }^{\mathrm{f}}$ Grupo de Espeleología Satorrak, calle Descalzos 37 bajo bis, 31001 Iruña-Pamplona, Spain \\ ${ }^{g}$ Instituto Internacional de Investigaciones Prehistóricas de Cantabria, Universidad de Cantabria, Avda. de los Castros s/n, Santander 39005, Spain
}

\section{A R T I C L E I N F O}

\section{Article history:}

Received 28 September 2017

Accepted 23 January 2018

Available online xxx

\section{Keywords:}

Geological risk assessment

Protection area

Karst

Rock art

Geographical Information Systems (GIS)

\begin{abstract}
A B S T R A C T
This paper sets out a methodology for calculating the potential zone of damage to which an Item of Cultural Interest (ICI) located in a karst environment is exposed. An itemised study of the geological characteristics of the cave environment is proposed: lithological cartography, endokarst and exokarst geomorphology and the study of fracturing of the limestone massif. Based on these data and using a Geographical Information System (GIS), it was possible to calculate the degree of the geological threats on a susceptibility map, according to the vulnerability of the heritage item to be protected and its exposure to the identified hazardous geological processes. By combining these parameters, the existing geological risk was calculated and mapped and the necessary protection area for conservation of the cultural heritage was defined. This methodology was applied in the Alkerdi caves located in the municipal area of Urdazubi/Urdax (Navarre, northern Spain).
\end{abstract}

(C) 2018 Elsevier Masson SAS. All rights reserved.

\section{Introduction}

Any discovery of rock art always poses a challenge for the researchers but also for authorities responsible for its management and protection. When artistic items are found in natural surroundings with no specific legal protection, it becomes necessary to modify the list of activities permitted in the area. Before any conservation or restoration work begins, it is necessary to analyse the natural and man-made dangers in the area and the vulnerability of the item or site, in order to decide where the protection area should be drawn to prevent any possible impact $[1,2]$.

Nowadays, there is no tested and globally accepted methodology for calculating geological risks in karst environments. Several proposals have been made, for instance, those by Carrasco et al. [3] (PROTEKARST), Angulo et al. [4] and Iriarte et al. [5], all of them based on overlapping different layers containing values of differ-

\footnotetext{
* Corresponding author.
}

ent factors and creating a zoning map. Similarly, when it comes to establishing the protection area for conserving an Item of Cultural Interest (ICI) located in a karst environment, there is no tested, objective, hierarchical model [5]. In the specific case of karst environments, where the natural and cultural heritage is closely related [6], any calculation of the possible risks entails complex studies. It is very difficult to devise universal methods that can be applied to all cases [2], although it is recommended to apply flexible methods, adaptable to the specific conditions of each region [6].

\section{Research aim}

The aims of this paper are to establish the methodology used to calculate geological risk indexes throughout karstic massifs, and to define the potential zone of damage and therefore, determine the protection area required for conserving the new rock art found in the Alkerdi 1 and 2 caves. This index was calculated based on the detected geological dangers, the vulnerability of the item to be conserved and its exposure to the identified geological threats. Due 

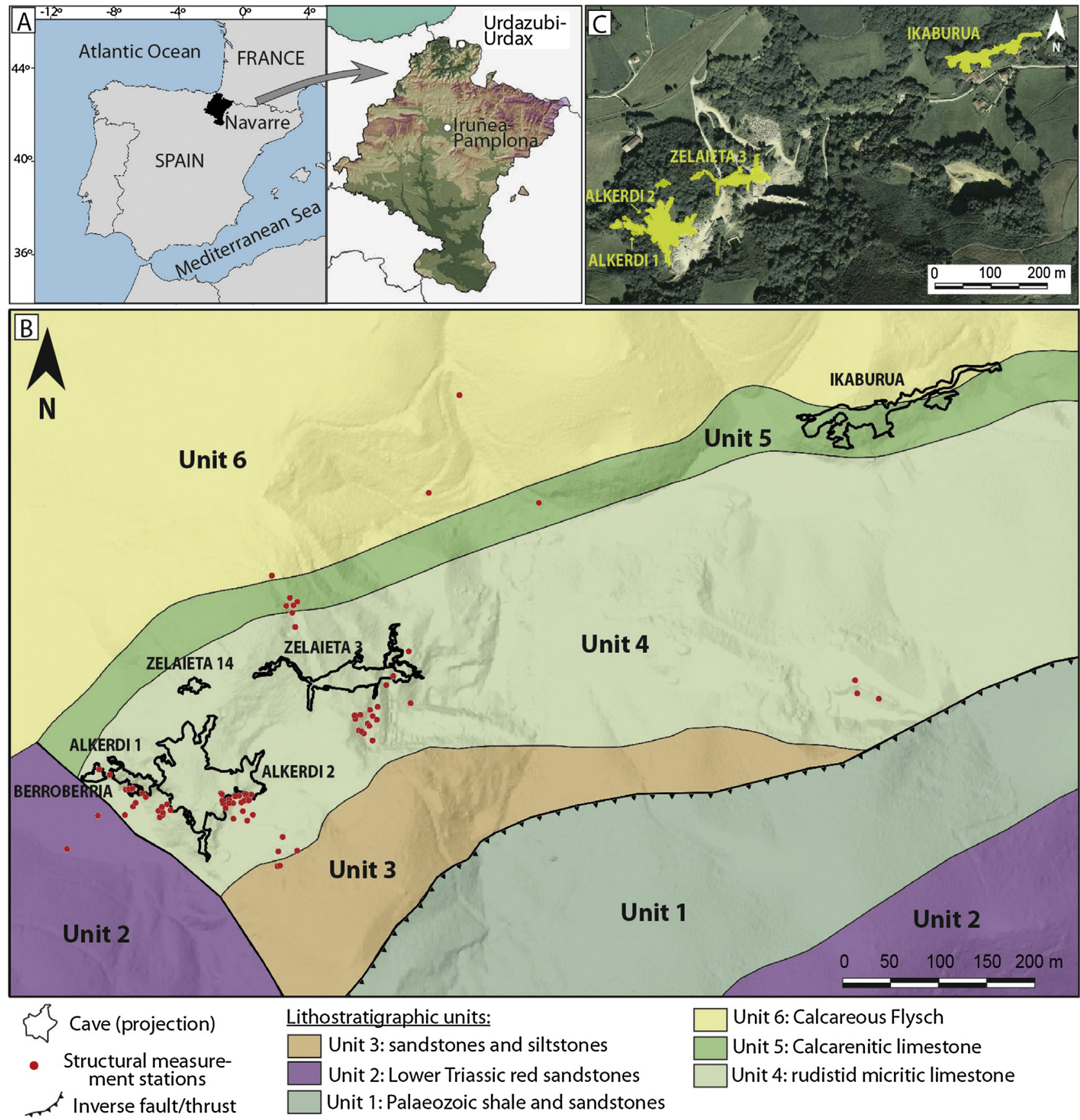

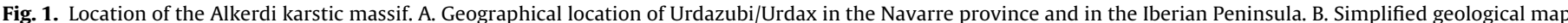

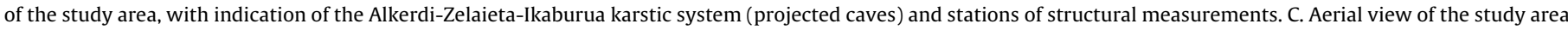
(with the quarry fronts) and the projection of the caves.

to its flexibility, this methodology is apt to be applied in any karst environment.

\section{Case study: the Alkerdi karst system}

The Alkerdi massif is located in the north of the province of Navarre (Spain), in the municipal area of Urdazubi/Urdax, adjacent to the French border (Fig. 1A). The massif is composed of Cretaceous reefal limestones that extend discontinuously in a SW-NE direction and overlie Lower Cretaceous sandstones, and are overlaid by calcareous Upper Cretaceous Flysch deposits (Fig. 1B). The SW limit of the massif is a Cretaceous fault, that puts it in contact with Lower Triassic sandstones and to the SE, Palaeozoic and
Triassic rocks overlap the Cretaceous succession by an Alpine thrust (Fig. 1B).

The massif contains an extensive karst system, the AlkerdiZelaieta-Ikaburu system (Fig. 1B and C), developed from $200 \mathrm{~m}$ to $120 \mathrm{~m}$ a.s.l, which is still under speleological/archaeological exploration. To date, 53 cave entrances, sinkholes and springs have been located in the study area (Fig. 1B). The karst system, structured into four cave levels running in a SW-NE direction (multi-level karst system), extends for more than $1 \mathrm{~km}$ and is composed of six main caves (Fig. 1B). One of these caves, Alkerdi 1, contain important items of rock art, including an ICI (engravings) [7,8], and new artistic manifestations were recently found (more than a dozen of paintings and engravings, archaeological hearths and material scatters) in 

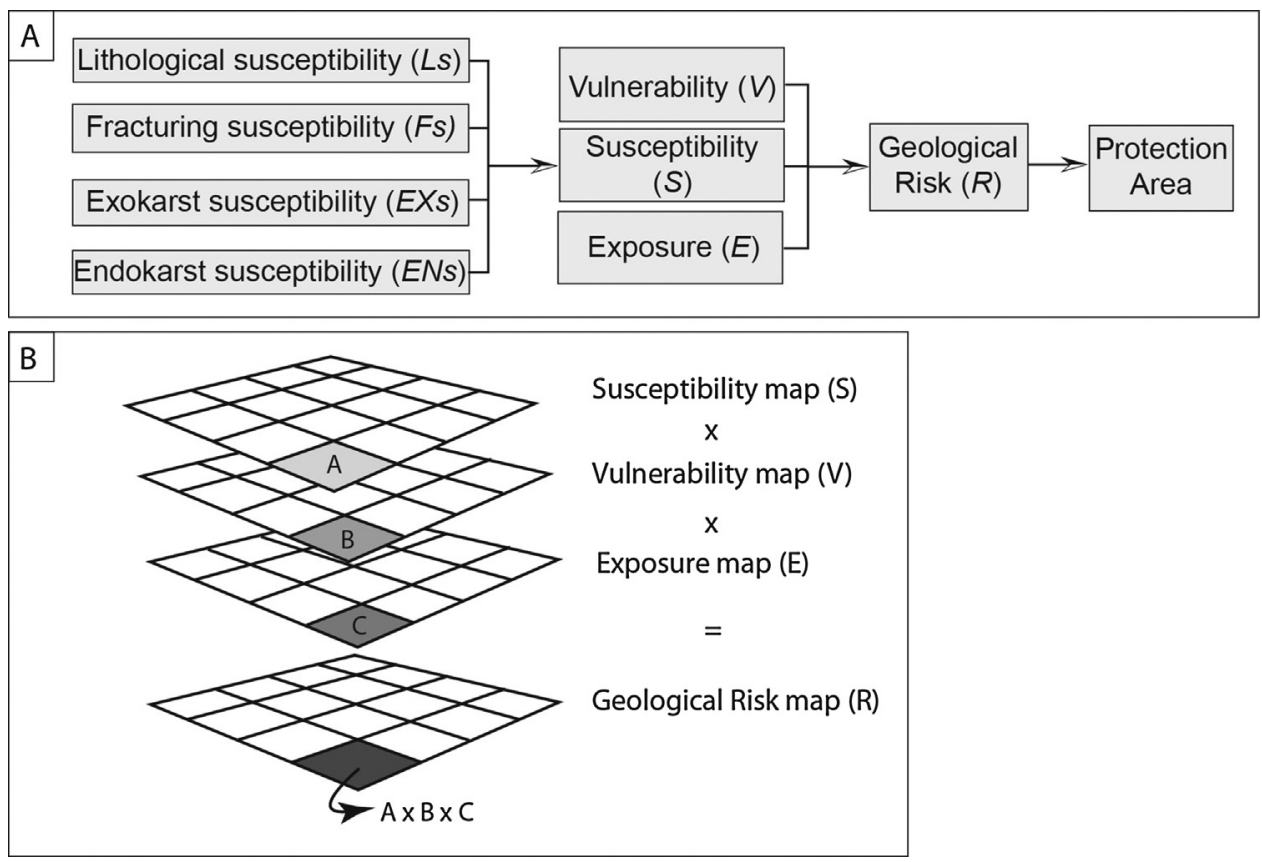

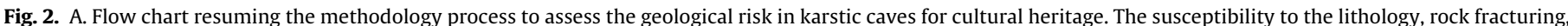

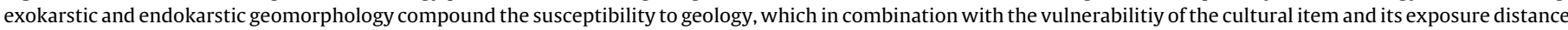

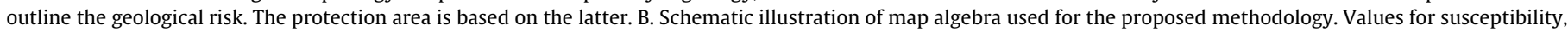
vulnerability and exposure were multiplied at each map cell/pixel to obtain the geological risk value for that cell/pixel.

the Alkerdi 2 cave [9], all of them located at the second karst level. The authority responsible for managing the caves commissioned a study of any geological threat that might damage these works of art, as well as the impact of the advance of the limestone quarry adjoining the cave (Fig. 1C).

\section{Methodology}

Any methodology used to determine the possible risk to the paintings and engravings must be based on an exhaustive knowledge of all processes that might affect the conservation of these items. Potential impacts on cave art can result from both geological (e.g. earthquakes, floods, etc.) and human derived hazards (e.g. rock extraction in quarries), though the latter are not considered in this study. In karst environments, geological risk relates to threats that might affect the environment of the item to be preserved. Since the cultural items of this study are in the uppermost karstic levels, only geological hazardous processes that might endanger the cultural items in those vadose cavities have been studied. We have considered as potential geological hazardous processes:

- water percolation within the karst system, as it can affect directly or indirectly the shelter of the art items, whether dissolving it or forming a new speleothem layer on top of it [10];

- changes of the atmospheric circulation, because changes in, for example, water condensation can produce the same effects as the latter case [11];

- wall and roof collapsing, which can destroy completely the access or even the cultural heritage itself [12].

The hazardous processes i) and ii) directly relate to the lithological, fracture and exokarst susceptibility. The structural characteristics of the Alkerdi massif and its fracture and conduit porosities, however, controls the endokarst susceptibility. So, in karst terrains, the rock matrix (micro) porosity related to the lithology, the fracture porosity controlled by the structural characteristics and the density of the conduit porosity (endokarst) could be considered features to assess the threat. Once established the potential geological processes, the methodology used involved the following steps $[5,13,14]$ (Fig. 2A):

- identification and analysis of the susceptibility $(S)$ to different geological characteristics of the karst environment, which depending on their own attribute, will be more or less affected by the defined hazardous processes. This involved characterising the rock massif (Fig. 2A);

- lithological susceptibility ( $L s)$ : based on its compositional, textural and weathering characteristics;

- fracturing susceptibility (Fs): based on the structural characteristics;

- exokarst susceptibility (EXs): based on the potential impact of the different geomorphologic (exokarstic) units and processes in the endokarst;

- endokarst susceptibility (ENs): based on the potential geological processes in a vadose cavity;

- calculation of the vulnerability $(V)$ of the rock art elements, both intrinsic and derived from the support and/or immediate environs of the elements to be assessed. Vulnerability represents the sensitivity to hazards of the items to be protected;

- calculation of the exposure $(E)$ defined by the degree to which they might be affected by a specific hazard. The exposure basically depends on the distance from the geological hazards;

- calculation of the geological risk $(R)$, which is the combination of the geological susceptibility, vulnerability and the exposure degree of the rock art;

- proposition of the protection area (PA), based on the geological risk assessment.

The analysis of the components of risk was backed by cartographic information of the survey area. This information was entered into a Geographical Information System (GIS) in order to calculate the geological risk map using raster layers and map algebra, and thus define a protection area [15]. Map algebra involves algebraic operations (addition, subtraction, etc.) for the same pixel 
Table 1

Summary with all the parameters and values used to assign the potential damage zone in different maps.

\begin{tabular}{|c|c|c|c|c|}
\hline & Very low & Low & High & Very high \\
\hline \multicolumn{5}{|l|}{ Susceptibility (S) } \\
\hline Ls & Unit 6 & Units 1 , unit 3 & Unit 2 & Units 4 , unit 5 \\
\hline Fs & RMR 0-40 & RMR 41-60 & RMR 61-80 & RMR 81-100 \\
\hline EXs & The rest of the massif & Covered lapies & Deep lapies; semi-covered lapies & Dolines; exhumed cavities \\
\hline ENs & The rest of the massif & $\begin{array}{l}\text { Areas inside de galleries } \\
\text { without evidence of } \\
\text { collapses nor active } \\
\text { speleothems }\end{array}$ & $\begin{array}{l}\text { Entrance area; active speleothem } \\
\text { formation zones; areas of colluvial } \\
\text { sedimentation }\end{array}$ & $\begin{array}{l}\text { Zones with evidence of } \\
\text { collapses }\end{array}$ \\
\hline \multicolumn{5}{|l|}{ Vulnerability (V) } \\
\hline The rest of the massif & $\begin{array}{l}\text { Security perimeter of } 10 \mathrm{~m} \\
\text { around high vulnerable } \\
\text { areas }\end{array}$ & $\begin{array}{l}\text { Galleries connected with } \\
\text { the exterior }\end{array}$ & $\begin{array}{l}\text { Galleries containing: art and/or } \\
\text { evidence of collapses }\end{array}$ & \\
\hline \multicolumn{5}{|l|}{ Exposure (E) } \\
\hline $\begin{array}{l}\text { More than } 75 \mathrm{~m} \text { from } \\
\text { the surface }\end{array}$ & $50-75 \mathrm{~m}$ from the surface & $25-50 \mathrm{~m}$ from the surface & $\begin{array}{l}\text { Cavities with rock art and less than } \\
25 \mathrm{~m} \text { from the surface; horizontal } \\
\text { distance }<100 \mathrm{~m} \text { from rock art }\end{array}$ & \\
\hline
\end{tabular}

in different layers (Fig. 2B). Thereby, the following maps were created for each component of risk: geological hazard map, vulnerability map and exposure map.

\section{Results and discussion}

\subsection{Susceptibility map (S)}

The geological and geomorphological susceptibility were analysed throughout the study area, in particular for the Alkerdi 1 and 2 caves (Fig. 1B). Measurement of the fractures and detailed geomorphology, however, was restricted to the area of the carbonate massif housing the karst system, i.e., to the area of direct impact. Within each of the hazards considered, the component variables were in turn defined and a map was created for each one. In these maps, the degree of susceptibility was assessed and represented qualitatively and quantitatively. All the parameters and values entered in the map algebra operation are summarized in Table 1.

\subsubsection{Lithological susceptibility map (Ls)}

It is based on the nature of the rock massif. Six lithostratigraphic units, both carbonate and siliciclastic, have been identified in the study area (Fig. 3A). Each of the different units was ascribed a value of lithological susceptibility (Table 1) depending on its compositional, textural and weathering characteristics (Fig. 3B).

The Palaeozoic shale and sandstones, Culm facies (Unit 1) and Lower Triassic sandstones, Buntsandstein facies (Unit 2) present siliceous cements and produce the steepest reliefs to the south of the thrust belt (Fig. 1B). The most competent materials in these units (sandstones) alternate with less competent materials (shales); this causes differential erosion that favours gravitational block fall and sliding. The material accumulated as a result of slides may be reworked and drawn into the endokarst system by nowadays active surface water flows through sinkholes, fissures and/or dolines. Due to the location of Units 1 and 2 in the area nearby the karst system (Fig. 1B), they were classed as highly susceptible areas (Fig. 3B).

The unit of Albian sandstones and siltstones (Unit 3) contains carbonated cement, thus increasing the degree of alteration resulting from chemical dissolution of the cement. There are no major slopes for slide generation and no evidence of historical slides or gravity falls have been observed. Therefore, the degree of susceptibility resulting from gravitational falls is low (Fig. 3B).

The Alkerdi caves develop in Unit 4 (red rudist-rich limestones). The limestone is micritic in nature with abundant bioclasts and massive (poorly stratified); it is a homogenous, compact rock, with an isotropic structure that is rigid to fracturing. However, dissolution, especially along structural discontinuities (fractures), is very effective-even more if the water is acidified by the soil it passes through. The extensive development of karst morphologies is an evidence of its very high susceptibility (Fig. 3B).

The limestone in Unit 5 is stratified and sandy calcarenitic to micritic in nature. The Ikaburua sector of the karstic system is developed in this unit. The grainy texture increase the rock matrix porosity [16] and also the danger of fracturing and collapsing of the rock. Thus, the susceptibility is very high in this unit (Fig. 3B).

Finally, Unit 6 is composed of flysch-type facies, formed by marly limestones and tabular silty to sandy marlstones. Their mixed composition favours weathering and the formation of soil, giving gentle reliefs. Despite their stratified character, there are no rocky reliefs and the danger of detachment is low; thus, the susceptibility to hazardous processes is very low (Fig. 3B).

\subsubsection{Fracturing susceptibility (Fs)}

Rock fracturing/discontinuities control the danger of rockfall in the interior of caves and seepage of dripping or ground water (fracture porosity) [16]. The structural characteristics of the rock massif were assessed: a total of 123 measurements of discontinuities were performed (Fig. 3C), characterising the parameters required to obtain Bieniawski's RMR index [17]. Following the methodology of Iriarte et al. [5], this index can be used to calculate several indices of geological quality and risk for the cavities in relation to its fracturing pattern $[2,5]$ (Table 1 ).

Up to 80 fracture discontinuities were measured and quantified (Fig. 3D). Although the limestone (Unit 4) is poorly stratified, there are sub-vertical bedding dips (approx. $60^{\circ}$ ) towards the north $\left(\mathrm{N} 351^{\circ} \mathrm{E}\right)(n=14)$. Locally, in the SSW edge of the massif, inverse stratifications were measured. The rest of the discontinuities could not be classified as one or other. The fractures have been grouped into three main sets (F1, F2 and F3) (Fig. 3D).

Fractures are mainly undulated/rough and flat/smooth type, with a moderately close spacing and a high level of continuity that varies from three to over $10 \mathrm{~m}$ (Fig. 3E). In general, the fractures are open to cavernous, with abundant indications of karst dissolution. Parallels can be observed between the main fracturing families and the karst cavities, suggesting their control on the formation and development of the karst galleries (Figs. 3D and E).

According to fracturing parameters observed in the rock massif, the RMR index [2,5] is 51 (Table 2). Consequently, the susceptibility to fracturing is low in the whole massif (Table 1 ).

\subsubsection{Exokarst susceptibility map (EXs)}

This map is based on the potential impact that the different exokarst geomorphologic units and processes might have for the 

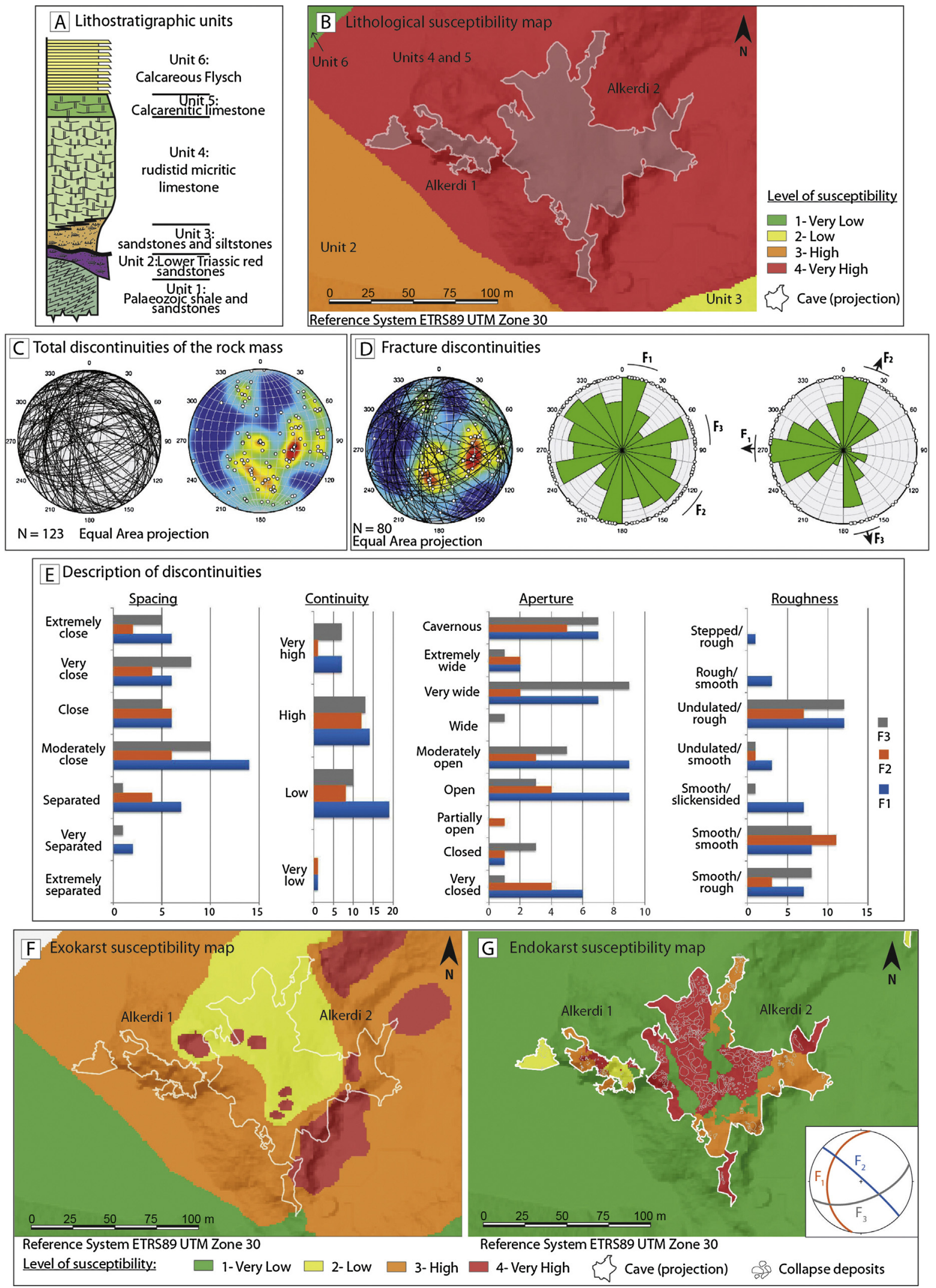

Please cite this article in press as: I. Álvarez, et al., Geological risk assessment for rock art protection in karstic caves (Alkerdi Caves, Navarre, Spain), Journal of Cultural Heritage (2017), https://doi.org/10.1016/j.culher.2018.01.017 
Table 2

Evaluation of the rock massif quality of the Alkerdi karstic massif, based on the RMR index [1].

\begin{tabular}{llr}
\hline Parameters & Value & Points \\
\hline Simple compression strength (MPa) & 100 & 12 \\
RQD (\%) & 100 & 20 \\
Spacing between discontinuities & Moderately close & 5 \\
State of discontinuities & High continuity, wide opening & 10 \\
Water circulation & Wet & 4 \\
& Total & 51 \\
\hline
\end{tabular}

endokarst system. The presence of different mapped karstic features and their characteristics control the degree of connection and environmental conditions of the interior of the karst system (air, humidity, CO2, dripping and seepage water, etc.). The susceptibility to the endokarst of each geomorphologic unit or area was assessed on the basis of its geomorphologic characteristics and karstic activity (Fig. 3F, Table 1):

- covered lapies: the existence of a sedimentary covering on the lapies, slows down the transmission of water- and air-flow between the exokarst and the endokarst [18]. Consequently, the susceptibility grade is low. It is worth noting the presence of a organic matter-rich horizon $(10-15 \mathrm{~cm})$, which favours acidification of meteoric water, facilitating dissolution of the limestone $[19,20]$;

- semi-covered lapies: in these areas a greater rate of seepage occurs, so these areas pose a high susceptibility grade;

- deep lapies: due to its large vertical development (>2 m) and high exterior-interior transfer, this area is highly susceptible;

- dolines: these areas with direct connection of the surface with the endokarst represent a very high susceptible area;

- exhumed cavities: these are parts of the endokarst network directly exposed to the surface, thus, these areas are prone to suffer hazardous processes. The alteration of the karst system could therefore pose a very high susceptibility degree.

\subsubsection{Endokarst susceptibility map (ENs)}

The dangers in the interior of a vadose karst cavity are related to the geological processes that can be caused by major and sudden changes in their physical and environmental conditions. Based on the geomorphological, structural and sedimentological evidences observed in the endokarst, areas of high to very high susceptibility degree were distinguished (Table 1, Fig. 3G), e.g.:

- the present entrance areas. Currently, practically no sedimentation processes are observed. However, because of their proximity to the surface, any environmental changes in the exterior could transfer to the interior, and this is therefore, considered an area of high susceptibility;

- active speleothem formation zones. Any environmental change in the exterior (temperature, soil $\mathrm{CO} 2$, pollution, etc.) will be transmitted to the karst system through seepage of dripping water, modifying physico-chemical conditions inside the cave and triggering damaging processes for the preservation of rock art, such as humidity, condensation derived corrosion, moonmilk precipitation, bacteria colonization, etc. These areas are very sensitive to any environmental change, and therefore have a very high degree of susceptibility. Areas with intense dripping, formation of speleothemes and dolines, close to the paintings and engravings, are also of high susceptibility zones;

- areas of colluvial sedimentation filling the caves. One of the dolines in the area of the quarrying operations stands at $30 \mathrm{~m}$ from the room containing the cave art in Alkerdi 2. In the interior of the cave, an alluvium cone has been observed coming from the doline, formed by clasts and abundant material derived from the quarry activity (rock fragments with cut marks, abrasive sand from quarries, ballpoint pens, etc.). From this same alluvium cone a runoff is reactivated which submerges into the room with the paintings and engravings in Alkerdi 2. This has, to a large extent, eroded the sedimentary fill on which hearths and archaeological remains have been found. Its presence indicates a direct connection between the interior and the exterior and is evidence of a delicate situation for the room with rock art and archaeological remains. These alluvium cones are unstable sedimentary bodies that can be reactivated by environmental changes (floods, etc.), and are therefore considered as highly susceptible areas;

- collapse evidence. The Alkerdi 2 cave shows collapse deposits covering the floor of the cavities, due to previously described fracture set intersections (Fig. 3G). The rockfall deposits are formed of angular decametric blocks, some of them corresponding to recent collapse events, whereas other would be older as they are fossilized by stalagmithic growth. This is an indication of the unstability, and therefore, dangerous nature of the galleries, exacerbated by indications of the existence of another cave level beneath the block pile. For this reason, the central area of Alkerdi 2 sector is of high susceptibility (Fig. 3G).

\subsubsection{Susceptibility map (S)}

This susceptibility map is the result of the sum of the different geological susceptibilities previously described $(L s+F s+E X s+$ $E N s$ ). The resulting map will have values ranging from 1 to 12 , since Fs is integrated in the ENs map (Fig. 4).

In the geological susceptibility map (Fig. 4) the Alkerdi 1 and 2 caves are the areas of greatest susceptibility (values $=9$ to 12). These values are the result of the fragility shown by some caves (abundance of gravitational collapse processes), the intense waterflow/dripping activity (large connection/transfer between the exokarst and the endokarst) and the geomorphology of the massif surface. The entire calcareous massif has a high susceptibility rate (values $=6$ to 8 ). The adjoining areas vary from medium values ( 4 to 6 ) on lithological units 2 and 4 to low values ( 1 to 3 ) for the areas located on lithological units 1 and 6 .

\subsection{Vulnerability map (V)}

The rock art to be protected (mainly engravings and paintings) is highly vulnerable to any physical and/or chemical environmental change, both in the endokarst and in the exokarst. The intrinsic vulnerability of the cave paintings depends on the composition of the pigments used for their manufacture, according to which their sensitivity to agents of alteration will vary. However, this vulnerability

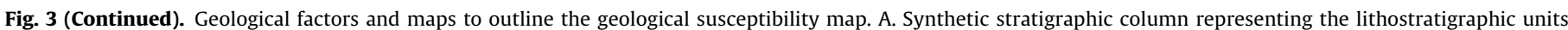

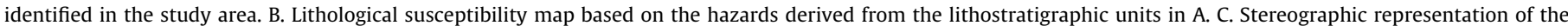

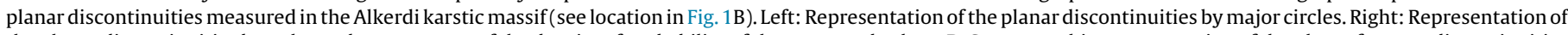

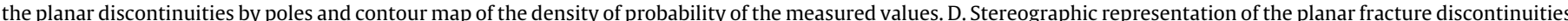

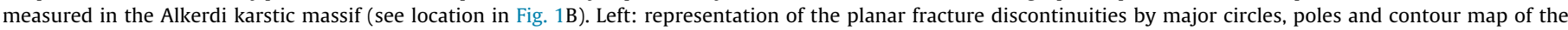

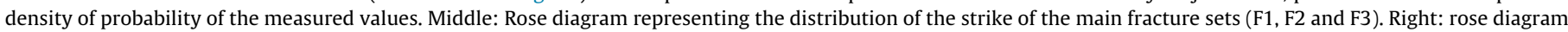

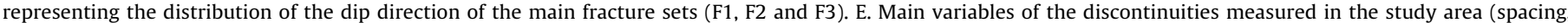

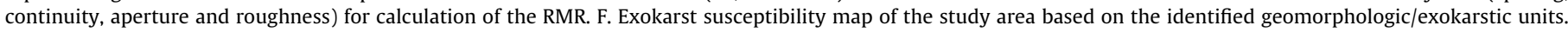

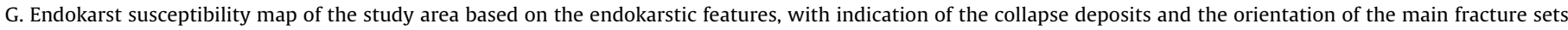
(inlet). 


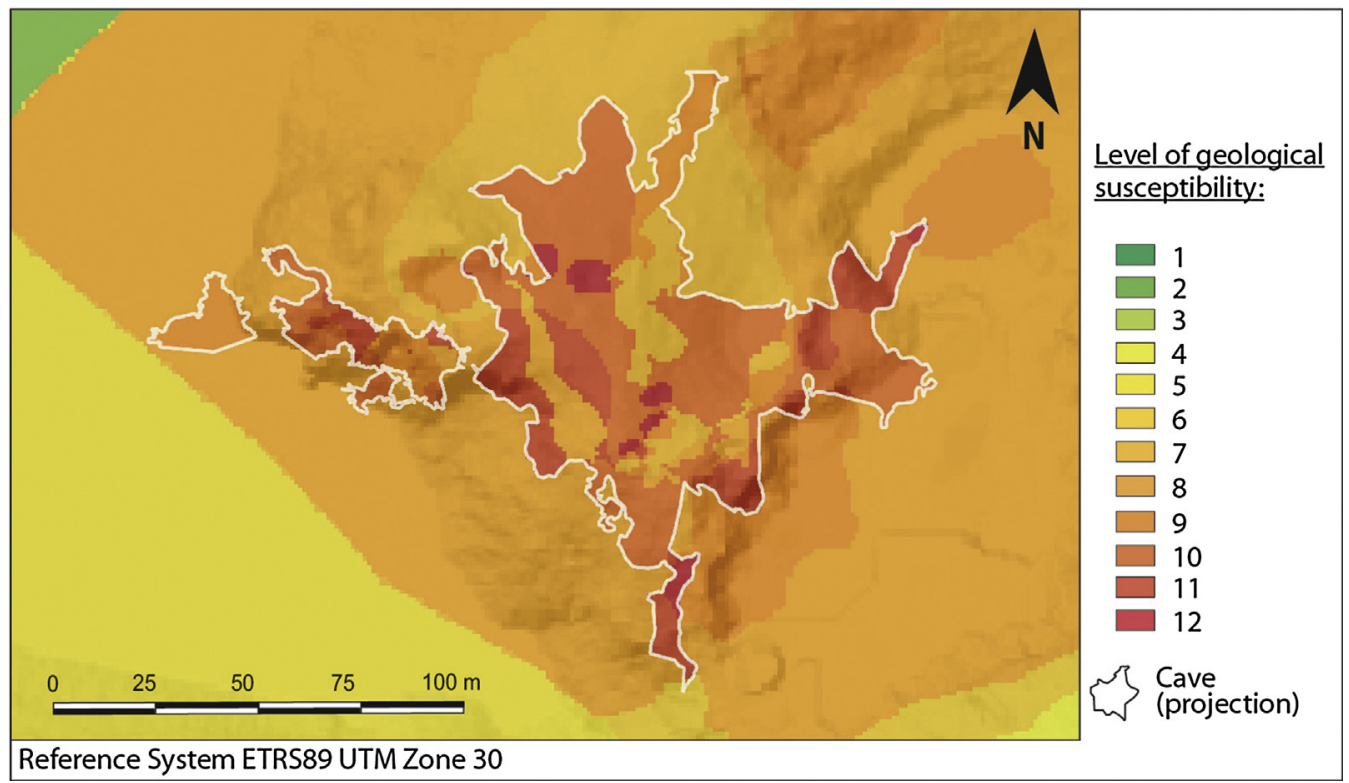

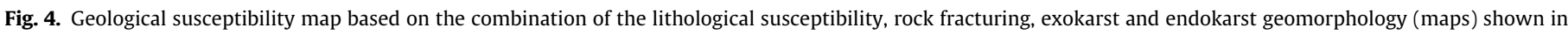
Fig. 3.

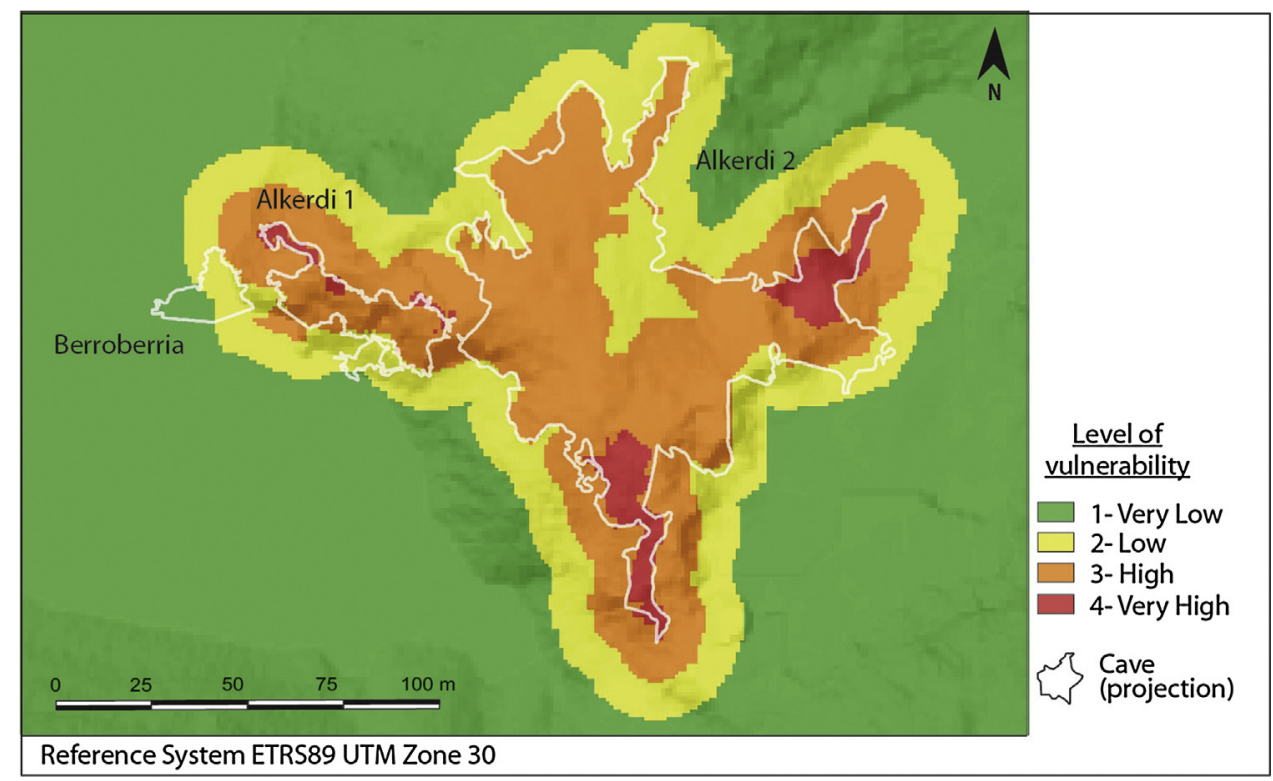

Fig. 5. Calculated map of the vulnerability for the Alkerdi karstic massif derived from the combination of the different fragility and supports of the archaeological items.

may also be conditioned by the fragility of the supports of the cave art itself. If the support is made up of speleothems, such as stalactites, draperies and flowstones, the level of vulnerability is accentuated by their fragility, crystalline structure and laminated internal texture. The speleothems are highly fragile to vibrations caused by tremors, whether the cause is natural (earthquakes) or human (quarrying activity and blasting, for example) [21-23]. In Alkerdi caves the rock art is found on both types of supports: limestone rock walls (engravings and paintings) and on speleothems (paintings).

As previously described, the presence of large blocks which have fallen from the walls and ceilings in Alkerdi 2 is an indication of the fragility of the rock in this area, especially in the areas of intersection between structural discontinuities, thus, these areas are classified as of very high vulnerability (Table 1, Fig. 5).
Moreover, the interaction between the underground and seepage water ( $\mathrm{pH}$, carbonate saturation, etc.), the characteristics of the air in the cavities (humidity, temperature, $\mathrm{CO} 2$, etc.), the biological agents and climate/topographical/geological conditions of the area in which the caves are located, generates a delicate balance of carbonate dissolution/precipitation processes. If this balance is altered it could drastically and irreversibly affect the rock art, so the entire karstic system is classified as low to highly vulnerable, depending on the connectivity with the exterior. The Alkerdi 1 cave communicates with the exterior through the entrance to the cavity (high vulnerability). The room in which the new Palaeolithic paintings and engravings are located in Alkerdi 2 must therefore be classed as being of the highest level of vulnerability. Given that the changes in the different environmental parameters are easily propagated through the karst, all the galleries containing art were catalogued 

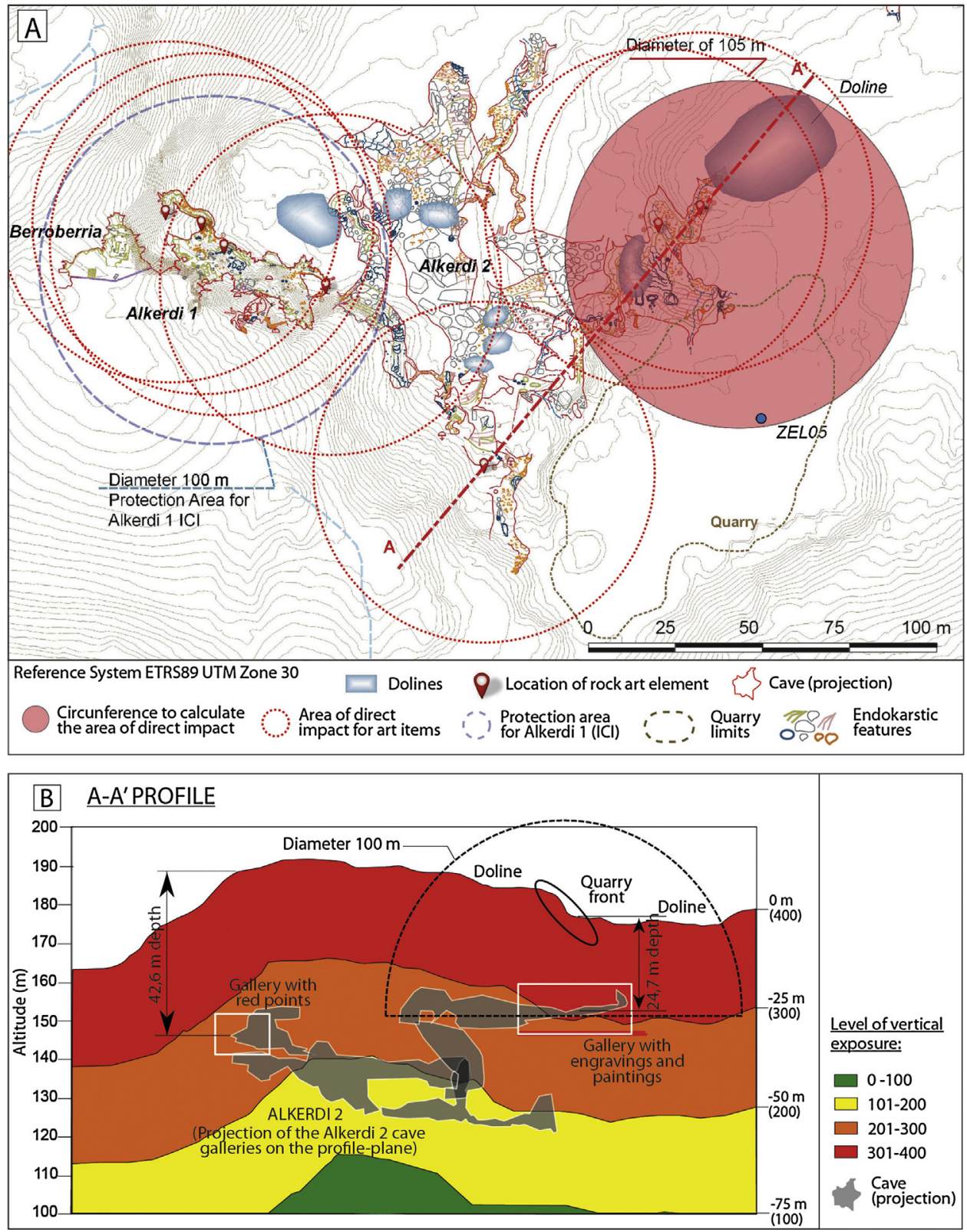

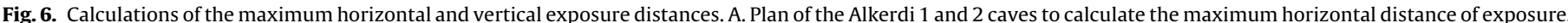

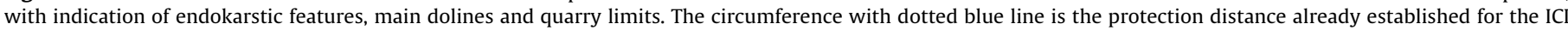

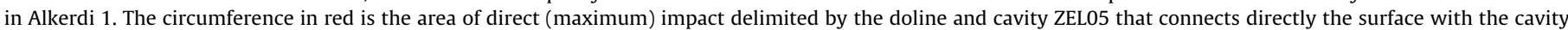

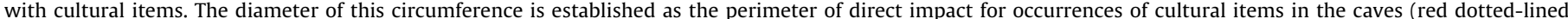

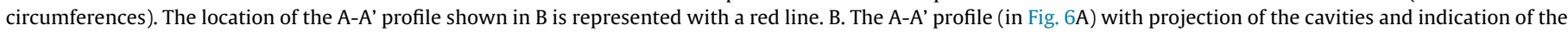

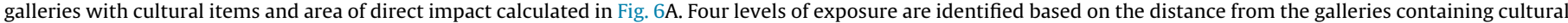
items to the surface.

as of very high vulnerability. To be conservative, a security area around the high vulnerability area is classified as low vulnerable (Fig. 5).

\subsection{Exposure map (E)}

The exposure depends, to a great extent, on the distance between the item to be conserved and the hazardous processes that might act on it. The environmental threats of the endokarst (e.g. changes in temperature, $\mathrm{CO} 2$ concentration, level of condensation and dew-point and air circulation) are easily transmitted through the karst system. Given the exposure to these hazards, the whole karst cavity, therefore, needs to be considered as a single entity. Because many of these environmental parameters are regulated/modified through the epikarst, the nearer the gallery containing the item to be protected is to the exterior surface, the greater the exposure.

For this reason, two distances were considered in drawing up the exposure map: on the one hand, the horizontal distance projected from the rock art panels to the different dangers (Fig. 6A); and on the other, the vertical distance from the art to the surface (Fig. 6B).

In order to establish the distance of maximum horizontal exposure in a karst system, which by definition contains a diverse distribution of geomorphologic elements (dolines, sinkholes, cavities, development of lapies, etc.), the area of direct impact on the item to be protected was defined and taken into account; i.e. the area of influence containing the elements of danger that might directly affect the item to be protected. In the case of Alkerdi 2, 


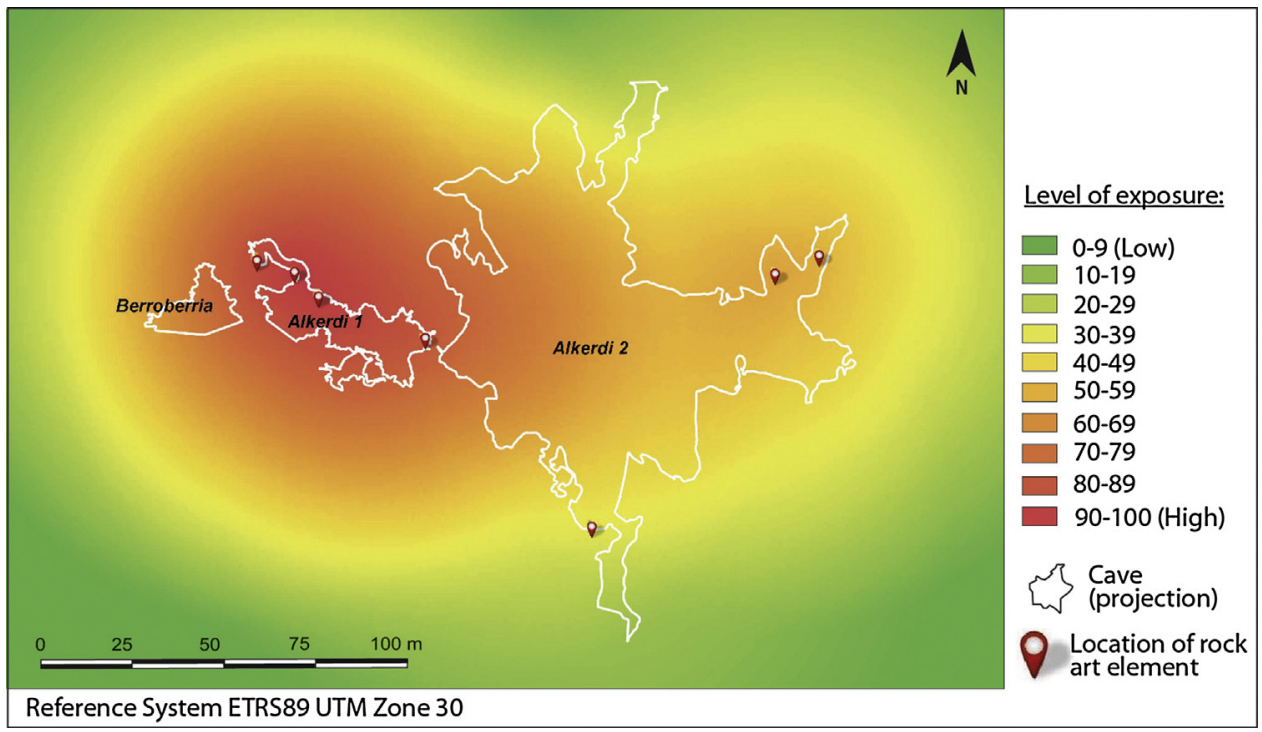

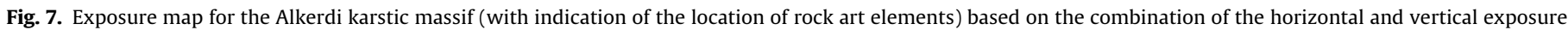
levels in Fig. 6.

and for the engraving and painting bearing room, the area of maximum impact is delimited by a doline which drains directly to the that room, and cavity ZEL05, located in the bottom of the quarry (Fig. 6A), which also connects directly to the cavity containing the paintings and the engravings. The diameter of the circumference encompassing the two elements (doline and dissolution pipe ZEL05) taking the rock art area to be protected as its centre, delimits the area of direct impact and, therefore, of maximum exposure to the hazards. The diameter of that area is ca. $105 \mathrm{~m}$ and defines the maximum area of horizontal exposure (Fig. 6A).

In the case of the Alkerdi 1 cave, the current distance of protection established for the engravings in the declaration of the ICI is $100-125 \mathrm{~m}$ from the entrance of the cave containing the cultural item (Fig. 6A) [24]. However, we consider that the reference point should be the cultural item itself, since the entrance may be situated at some distance from the item and might even stand outside the area of direct impact. Based on the above, it was established that in this case the perimeter of protection/direct impact should be set at approximately 100 metres (Table 1 ), for calculating the areas of direct impact for each panel of paintings and engravings throughout the karst system (Fig. 6A).

In order to calculate the vertical distance from the panels with rock art to the surface, the roof of the cavities where they are located was considered. The distance to the surface was calculated using the digital model of elevations of the surface of the Alkerdi massif (Fig. 6B). The values obtained were then inverted, given that greater distances will have less exposure and shorter distances will have greater exposure.

Taking into account:

- the highest painting bearing room top is only $24.7 \mathrm{~m}$ deep;

- that this ceiling (and floor) has evidence of rock fall;

- the deep and penetrative development of fractures and the lapies;

- the high development of dolines and sinkholes, some of them directly connected with cavities located at less than 25 m deep (e.g. ZEL05);

- and the high level of connection between the exokarst and endokarst, it was determined that the exposure to geological threats was greatest "very high" in cavities with rock art whose ceilings are less than $25 \mathrm{~m}$ from the surface; "high" in those located at $25-50 \mathrm{~m}$ from the surface; "low" at 50-75 $\mathrm{m}$ and very low at over $75 \mathrm{~m}$; and in non-karstic areas (see the A-A' profile in Fig. 6B). Thus, the profile shows 4 vertical exposure levels (Table 1).

The exposure is highest in the locations with rock art, close to the surface or to areas of direct impact and falls to zero away from these points to a horizontal distance of 100 metres. Depending on the vertical distance to the surface (which has been determined in four levels and is multiplied by the horizontal exposure), the maximum exposure values of points located at a distance of less than 25 metres are considered to range from 400 to 301 ; in points located between 25 and 50 metres from the surface, from 300 to 201; between 50 and 75 metres from the surface, 200 to 101, and finally, all rock art sites located at a depth of more than $75 \mathrm{~m}$ would have an exposure ranging from 100 to 0 . It is thus possible to take both the horizontal and vertical distances into account in a single map. By combining all the circles of direct impact (seven rock art areas from Alkerdi 1 and Alkerdi 2 were considered) we get the exposure map shown in Fig. 7. Values obtained from the sum of all the circles have been reclassified on a scale of 1 to 100 .

\subsection{Geological risk map}

The aim of the risk map is to determine the damage that might be caused to the natural and archaeological heritage of the interest area as a result of geological hazards. The magnitude of the overall geological risk $(R)$ depends on a combination of different components of risk $[13,14,25]$ that include: the geological susceptibility map $(S=L S+F s+E X s+E N s)$, the vulnerability $(V)$ and the exposure $(E)$ of the items to be protected.

The risk from geological agents is the sum of the different hazards, multiplied by the exposure and vulnerability of the item to be protected (see the formula below), in this case, the archaeological areas containing Palaeolithic rock art. This has been calculated for each pixel:

$$
R=(L s+F s+E X s+E N s) * V * E
$$

This final map was reclassified with values varying from 1 (lowest risk) to 10 (highest risk) (Fig. 8). As can be seen in the map, the area containing the Alkerdi 1 and 2 caves stands almost entirely within an area of maximum risk, given that these are the most 


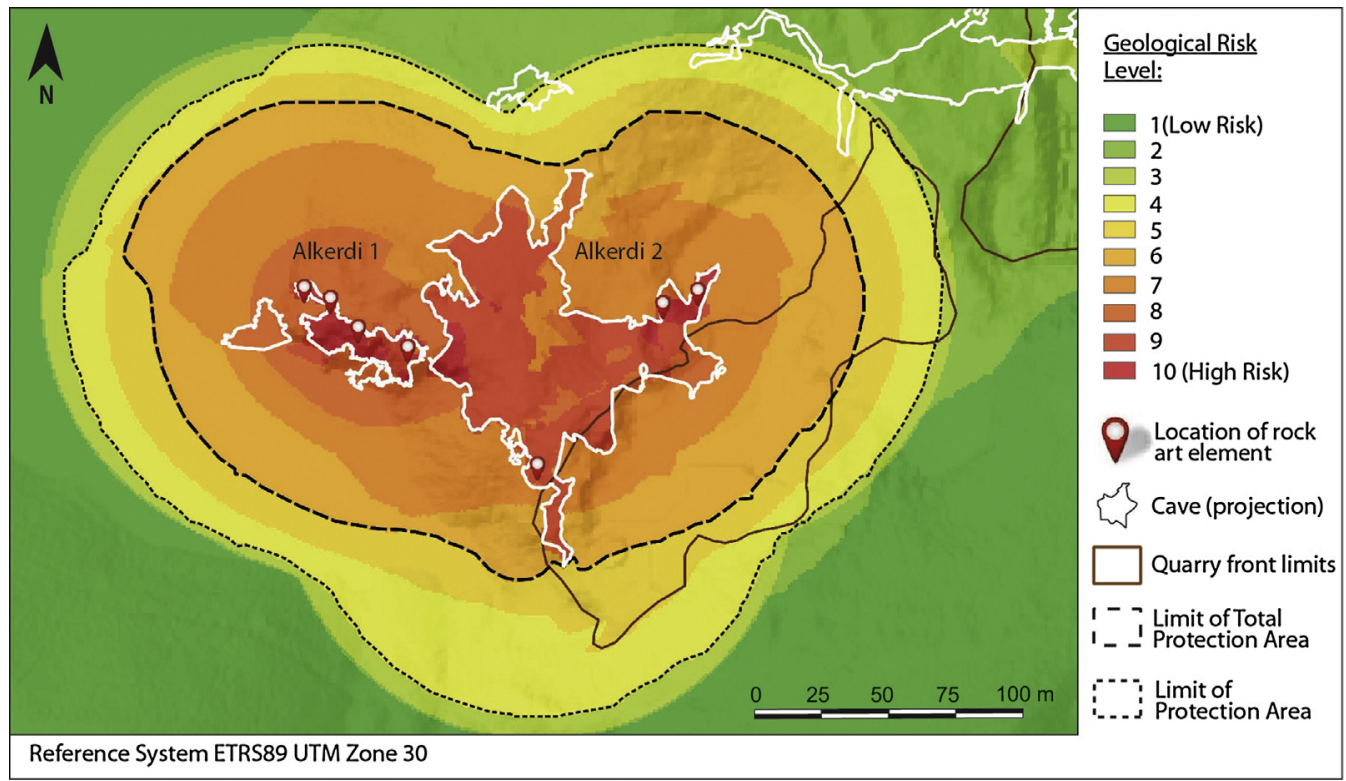

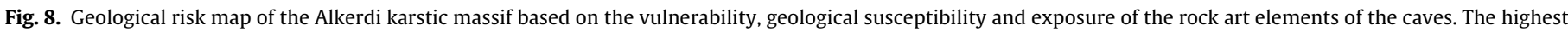
risk levels (6-10) delimit the Total Protection Area (TPA) and the Protection Area (PA) is delimited by values 4 to 5.

vulnerable areas (because of the presence of rock art areas) and also the most exposed. The rest of the karstic massif lies within an area of low risk (value 2 or 3 ).

\subsection{Protection area}

The geological risk map (Fig. 8) shows the potential zone of damage. Therefore, in order to protect the different rock art bearing areas in the Alkerdi karstic massif, protection area should be extended at least as far as the quarry front, given that there is a distance of only $24 \mathrm{~m}$ between the active quarry (it is also inside the direct impact area) and the rock art panels (Fig. 6). The protection area was drawn based on an analysis of the geological risks set out above. It covers all the cavities, galleries and sinkholes in the karst system that have a direct connection with the caves containing rock art (Alkerdi 1 and 2), as well as the area of direct water recharge located above the caves to be protected. It also includes the immediate environs of all the areas of access to the cave (natural and man-made) and those areas that significantly influence the ventilation and exchange of gases between the caves and the exterior (dolines, sinkholes, open fissures, etc.).

Thus, based on the different levels of risk defined, the protection area was divided into two sectors (Fig. 8): a first sector, called Total Protection Area (TPA), which covers the area with risk values between 6 and 10. This area requires the maximum degree of protection and conservation, with absolute preservation of the drainage system, and of the characteristics and properties of the rock massif containing the cavities with archaeological finds and the overlying soil coverage; and a second area, known as the Protection Area (PA), which covers the risk values between 4 and 5 , encompassing the rock massif and karst system adjacent to the TPA. This area hosts cavities that potentially are linked to those containing the rock art, and environmental changes may be transferred to them. Moreover, and since the area is under speleological/archaeological exploration, cavities under this area may potentially host new archaeological remains. Therefore, this area requires a high degree of conservation, with restriction of activities that may potentially damage the karst system, especially those that may reduce the rock volume (distance between cave and exterior) or the overlying soil coverage.

\section{Conclusions}

The assessment of the potential zone of damage of the cavities containing rock art in the Alkerdi karstic massif (Navarre, Spain) was done based on the following parameters: the geological susceptibility, vulnerability and exposure. The geological susceptibility is based on:

- the lithology, which controls the rock matrix porosity and seepage of the karst massif;

- the structural pattern or fracturing system, which controls the geological quality, dripping water for the cavities and rockfall processes;

- and the geomorphologic (exokarstic and endokarstic) features, which control the exchange of sediment, water and gases between the exterior and the caves. The fracture porosity is well correlated with the exokarst development and represents the main control on the susceptibility.

The vulnerability risk depends on the intrinsic fragility of the rock art (i.e. composition of pigments) and also on the vulnerability of the walls and/or speleothems where are performed, as well as on the environmental changes that can occur on the cavity.

Finally, the exposure risk of the item is inverse to the distance between the item to be protected and the geomorphologic elements (i.e. lapies, dolines, quarry-front in direct impact areas) that could affect them, and the surface. The analysis of each components of risk was entered into a GIS in order to calculate the risk map and therefore, define the protection area.

Based on the geological risk map, the protection area should cover all the geomorphologic elements that have a direct impact on the caves containing rock art, as well as the area of direct water recharge above the levels of those caves. The immediate areas that can significantly influence the ventilation and exchange of gases of the protected caves should also be delimited.

This methodology can be applied to assess the potential zone of damage and protection area of cavities containing rock art (engravings and paintings) in any karst environment. The application of this methodology in other examples will validate its efficacy. 


\section{Acknowledgements}

This study is a contribution of the Aranzadi Society of Sciences within the framework of the project Caracterización del Macizo y sistema kárstico de Alkerdi y de su perímetro de protección, funded by the Government of Navarre. Additional funding was provided by projects EHU-US'14/16 and EHUA15/18 (University of Basque Country) and IT1029-16_GBV6 (Basque Government). M. del Val was beneficiary of a predoctoral grant of the Basque Government (BFI-2012-289) during this project. The authors acknowledge Tim Nicholson for his help with the English editing. The authors would like to acknowledge anonymous reviewers for critical comments and suggestions that improved the original manuscript.

\section{References}

[1] R.J. Allison, Applied geomorphology: theory and practice, 10, John Wiley \& Sons, West Sussex (New York), 2002 [International Association of Geomorphologists].

[2] M.A. Sánchez, A. Foyo, C. Tomillo, E. Iriarte, Geological risk assessment of the area surrounding Altamira Cave: a proposed natural risk index and safety factor for protection of prehistoric caves, Eng. Geol. 94 (3-4) (2007) 180-200, http://dx.doi.org/10.1016/j.enggeo.2007.08.004.

[3] F. Carrasco, P. Jiménez-Gavilán, J.M. Thode, M.I. Fiestas, R. Fernández, Interaction between infrastructures and karst. Protekarst analysis method, Proceedings of the XVI ECSMGE, Geotechnic. Eng. Infrastruc. Develop. (2015) 2257-2262, http://dx.doi.org/10.1680/ecsmge.60678.

[4] B. Angulo, T. Morales, J.A. Uriarte, I. Antigüedad, Implementing a comprehensive approach for evaluating significance and disturbance in protected karst areas to guide management strategies, J. Environment. Manage. 130 (2013) 386-396, http://dx.doi.org/10.1016/j.jenvman.2013.08.057.

[5] E. Iriarte, M.Á. Sánchez, A. Foyo, C. Tomillo, Geological risk assessment for cultural heritage conservation in karstic caves, J. Cult. Herit. 11 (3)(2010) 250-258, http://dx.doi.org/10.1016/j.culher.2009.04.006.

[6] M. Jiménez-Sánchez, M.J. Domínguez-Cuesta, A. Aranburu, E. Martos, Quantitative indexes based on geomorphologic features: A tool for evaluating human impact on natural and cultural heritage in caves, J. Cult. Herit. 12 (3) (2011) 270-278, http://dx.doi.org/10.1016/j.culher.2011.01.004.

[7] N. Casteret, Une nouvelle grotte à gravures dans les Pyrénées. La grotte d'Alquerdi, in: XV Congrès International d'Anthropologie et d'Archéologie Préhistori-ques, 1933, pp. 384-389.

[8] D. Garate Maidagan, O. Rivero Vilá, La “Galería de los bisontes”: un nuevo sector decorado en la cueva de Alkerdi (Urdazubi/Urdax, Navarra), Zephyrus: Revista de prehistoria y arqueología, 75, 2015, pp. 17-39, http://dx.doi.org/10.14201/zephyrus2015751739.

[9] I. Álvarez, V. Abendaño, A. Aranburu, M. Arriolabengoa, A. Bodego, J.I. Calvo, et al., Estudio interdisciplinar del macizo kárstico de Alkerdi: rasgos geológicos, evolución kárstica y contenido arqueo-paleontológico, Trabajos Arqueol. Navarra 28 (2016) 193-227.

[10] A. Aranburu, I. Vadillo, L. Damas, P. García-Garmilla, P. Iridoy, M. Arriolabengoa, et al., Degradación de los espeleotemas de la cueva Praileaitz I (Deba, Gipuzkoa), in: J.J. Duran, F. Carrasco (Eds.), Cuevas: patrimonio, naturaleza, cultura y turismo, ACTE, 2010, pp. 235-449.

[11] B. Lismonde, Climatologie du monde souterrain : aérologie des systèmes karstiques, 2, Comité départamental de spéléologie de l'Isère, Grenoble, 2002.

[12] T. Waltham, F. Bell, M. Culshaw, Sinkholes and Subsidence, in: Karst and cavernous rocks in engineering and construction, Springer-Verlag, Berlin Heidelberg New York, 2005.

[13] Secretaría General de Vivienda de España, Guía metodológica para la elaboración de cartografía de riesgos naturales en España, Colegio Oficial de Geólogos, Madrid, 2008.

[14] F.J. Ayala Carcedo, J. Olcina Cantos, Riesgos naturales, Ariel (2002).

[15] J. Elez, S. Cuezva, A. Fernandez-Cortes, E. Garcia-Anton, D. Benavente, J.C. Ca-ñaveras, et al., A GIS-based methodology to quantitatively define an adjacent protected area in a shallow karst cavity: the case of Altamira cave, J. Environ. Manage. 118 (2013) 122-134, http://dx.doi.org/ 10.1016/j.jenvman.2013.01.020 [3/30].

[16] D. Ford, P. Williams, Introduction to Karst, Karst Hydrogeol. Geomorphol. (2007) 1-8.

[17] Z.T. Bieniawski, Engineering rock mass classifications: a complete manual for engineers and geologists in mining, civil and petroleumengineering, John Wiley \& Sons, New York, 1989.

[18] M. Veress, Investigation of covered karst form development using geo-physical measurements, Z. Geomorphol. 53 (4) (2009) 469-486, http://dx.doi.org/10.1127/0372-8854/2009/0053-0469.

[19] H.A. Barton, Biospeleogenesis, in: J.F. Shroder(Ed.), Treatise on geomorphology, Academic Press, San Diego, 2013, pp. 38-56.

[20] E. Pardo-Iguzquiza, J. Durán Valsero, J.A. Luque-Espinar, P.A. Robledo-Ardila, S. Martos-Rosillo, C. Guardiola-Albert, et al., Karst massif susceptibility from rock matrix, fracture and conduit porosities: a case study of the Sierra de las Nieves (Málaga, Spain), Environment. Earth Sci. 74 (2015) 7583-7592, http://dx.doi.org/10.1007/s12665-015-4545-x.

[21] É. Gilli, Review on the use of natural cave speleothems as palaeoseismic or neotectonics indicators, Comptes Rendus Geosci. 337 (13) (2005) 1208-1215.

[22] V. Garduño-Monroy, R. Pérez-López, M.A. Rodríguez-Pascua, J. García Mayordomo, I. Israde-Alcántara, J. Bischoff, Could large palaeoearthquakes break gi-ant stalactites in Cacahuamilpa Cave? (Taxco, Central Mexico) (Conference Paper), in: 2nd IN-QUA-IGCP-567 Proc, 2011, pp. 50-53.

[23] M. Akgöz, M. Eren, Traces of earthquakes in the caves: Sakarlak ponor and Kepez cave, Mersin (southern Turkey), J. Cave Karst Stud. 77 (1) (2015) 63-74, http://dx.doi.org/10.4311/2013ES0120.

[24] Gobierno de Navarra, Orden Foral 156/1995, de 24 de Abril, del Consejero de Educación y Cultura, por la que se incoa expediente de declaración de Bien de Interés Cultural a favor de la zona arqueológica denominada cueva de Berroberria, sita en el término municipal de Urdazubi/Urdax (Navarra), Bol. Navarra 67 (1995) 3267.

[25] F.J. Ayala, J. Olcina, Riesgos naturales y desarrollo sostenible: impacto, predicción y mitigación, 10, Publicaciones del Instituto Geológico y Minero de España, Instituto Geológico y Minero de España, 2007. 